

\title{
Urban dew and rain in Paris, France: Occurrence and physico-chemical characteristics
}

Daniel Beysens, A. Mongruel, K. Acker

\section{To cite this version:}

Daniel Beysens, A. Mongruel, K. Acker. Urban dew and rain in Paris, France: Occurrence and physico-chemical characteristics. Atmospheric Research, 2017, 189, pp.152 - 161. 10.1016/j.atmosres.2017.01.013 . hal-01494435

\section{HAL Id: hal-01494435 \\ https://hal.sorbonne-universite.fr/hal-01494435}

Submitted on 23 Mar 2017

HAL is a multi-disciplinary open access archive for the deposit and dissemination of scientific research documents, whether they are published or not. The documents may come from teaching and research institutions in France or abroad, or from public or private research centers.
L'archive ouverte pluridisciplinaire HAL, est destinée au dépôt et à la diffusion de documents scientifiques de niveau recherche, publiés ou non, émanant des établissements d'enseignement et de recherche français ou étrangers, des laboratoires publics ou privés. 


\title{
Urban dew and rain in Paris, France: Occurrence and physico-chemical characteristics
}

\author{
D. Beysens ${ }^{1,2}$, A. Mongruel ${ }^{1}$, K. Acker ${ }^{2,3}$ \\ ${ }^{1}$ Physique et Mécanique des Milieux Hétérogènes, UMR 7636 CNRS - ESPCI - Université \\ Pierre et Marie Curie - Université Paris Diderot, 10 rue Vauquelin, 75005 Paris, France \\ ${ }^{2}$ OPUR, 60, rue Emeriau, 75015 Paris, France \\ ${ }^{3}$ Brandenburg University of Technology Cottbus-Senftenberg, Institute for Environmental \\ Sciences, Germany
}

\begin{abstract}
This paper summarizes one year (April 2011 to March 2012) measurements on planar condensing surfaces of dew and rain events and related physico-chemical characteristics in the urban environment of Paris (city center). Yearly collected water was $3.48 \mathrm{~mm}$ for dew (63 events) and $593 \mathrm{~mm}$ for rain (146 events). The latter value compares well with rain data (547 mm and 107 events) collected within $12 \mathrm{~km}$ at Paris-Orly airport. An estimation of dew yield based on meteo data gives $2.35 \mathrm{~mm}$ and 74 events, to be compared with $17.11 \mathrm{~mm}$ and 196 events at Paris-Orly. These differences highlight the large reduction in dew events and dew yields in an urban area as compared to a close rural-like area. This reduction is not due to a sky view reduction but to heat island that increases air temperature and decreases relative humidity.
\end{abstract}

Analysis of dew (34) and rain (77) samples were done concerning $\mathrm{pH}$, electrical conductivity (EC), major anions and cations as well as selected trace metals and other minor ions. Mean $\mathrm{pH}$ values are found similar for both, dew (6.5) and rain (6.1), rain being slightly more acidic than dew. The mean dew total ionic content (TIC $1.8 \mathrm{meq} / \mathrm{l})$ and EC value $\left(124 \mu \mathrm{S} . \mathrm{cm}^{-1}\right)$ are about four times that of rain $\left(0.45 \mathrm{meq} / \mathrm{l} ; 35 \mu \mathrm{S} . \mathrm{cm}^{-1}\right)$, meaning that total dissolved solids in dew is nearly four times that in rain. Sulfate and nitrate are the most acidifying components, calcium the most neutralizing constituent with ratio of mean total acidity/total alkalinity comparable for dew and rain $(\sim 0.9)$. Sulfate and nitrate have mainly anthropogenic sources, whereas chloride and magnesium are mostly connected with marine air masses. Dew is a 
considerable factor of wet deposition of pollutants; ion concentrations, however, meet the WHO requirements for drinking water.

\section{Keywords:}

Dew water; Urban dew water; Rainwater; Water chemistry; Water quality; Paris (France)

\section{Highlights:}

One year (01/04/2011 - 31/03/2012) collection of dew and rain samples in Paris

Dew yield is 5 times lesser in Paris center than in suburb due to heat island

Dew and rain show similar ionic characteristics but dew has 4 times more TDS

Lead concentrations are small in both dew and rain water

Dew and rain water meet WHO requirements for potable water 


\section{Introduction}

Dew is the result of passive condensation of atmospheric water vapor into liquid. The necessary cooling power is provided by the radiation deficit between atmosphere and the condensing support. Dew has not to be confused with fog or rain, constituted of already condensed liquid droplets. With typically less than $70 \mathrm{Wm}^{-2}$ radiative power available, the maximum yield cannot exceed $0.7-0.8$ lm $^{-2}$ (Monteith and Unsworth, 1990; Beysens, 1995; 2006; Berkowicz et al., 2004). This low yield, however, can be a welcome and useful contribution to the biosphere (Zangvil, 1996; Agam and Berliner, 2006; Jacobs et al., 2006; Kidron et al., 2011; Uclés et al., 2013) and to potable water in arid or semi-arid climates (Nilsson, 1996; Beysens and Milimouk, 2000; Kidron, 2000; Beysens et al., 2006a; Lekouch et al., 2012; Tomaszkiewicz et al., 2015; Khalil et al., 2016; Mylymuk-Melnytchouk and Beysens, 2016), provided that water chemical and biological quality is acceptable (Beysens et al., 2006b; Muselli et al., 2006; Lekouch et al., 2011; Tomaszkiewicz et al., 2015). It can be also the source of plant disease (Luo and Goudriaan, 2000) and, in urban areas, cause degradation to roofs, cars and generally to any inorganic matter that can be corroded (Rubio et al., 2001, 2002; Xu et al., 2001). Dew formation is a local phenomenon. The steps governing dew chemical composition are formation on dry deposition solids, dissolution of the soluble portion of the dry deposition by dew water, and sorption of gases into the dew solution.

For any precipitation to fall there is a need for a cloud. Clouds are formed when the relative humidity reaches $100 \%$ and with enough hygroscopic nuclei in air so that condensation can take place. Cloud droplets initially grow quickly but to eventually produce precipitation collision / coalescence processes are needed. When drops become heavy enough to overcome air resistance they fall as rain. The chemical composition of precipitation is a result of three different processes: nucleation scavenging (chemical configuration of nuclei determines initial cloud composition), in-cloud scavenging (take up of non-activated particles and trace gases (major important) including chemical reactions within droplets), sub-cloud scavenging (absorption of gases and take up of particles). Not every cloud brings rain and on average a condensation nuclei may undergo many cloud cycling processes including chemical transformation before it comes back to earth surface, often far away from its primary source.

Carbon dioxide plays a special role in the formation of acidity in the atmospheric liquid phase because of its high and constant concentration. An important pathway in alkalinity (carbonate) formation goes via condensation nuclei (nucleation and droplet formation) as well as aerosol scavenging. The last process contributes significantly to sub-cloud scavenging into falling raindrops. The ability to capture particulates is very relevant for dew chemical 
composition and is strong at the beginning and weakened at the end of the condensation process. The acidity from dissolved $\mathrm{CO}_{2}, \mathrm{SO}_{2}$, and $\mathrm{NO}_{\mathrm{x}}$ is mostly neutralized by $\mathrm{Mg}^{2+}, \mathrm{Ca}^{2+}$ and $\mathrm{NH}_{4}{ }^{+}$; sometimes a slight alkaline character is observed in dew samples. Dew events with the higher ionic concentration occur following long periods without rain.

Uptake of high soluble gases on atmospheric water is very fast and not a question of time. Cloud cycling processes, microphysical conditions and heterogeneous reactions will influence dew and rain chemistry. When in equilibrium with atmospheric $\mathrm{CO}_{2}$, the $\mathrm{HCO}_{3}{ }^{-}$concentration is an exponential function of the $\mathrm{pH}$-value. When the $\mathrm{pH}$ solutions is higher than 6.35 (pKa1 of $\left.\mathrm{H}_{2} \mathrm{CO}_{3}\right)\left[\mathrm{HCO}_{3}{ }^{-}\right]$can become important. But samples of the atmospheric multiphase system are most probably not in equilibrium with atmospheric $\mathrm{CO}_{2}$ due to complex chemical compositions, microphysical processes and heterogeneous interactions and $\left[\mathrm{HCO}_{3}^{-}\right]$can only be obtained by analytical estimation and not deriving Henry's law. A possible high contribution of bicarbonate to the ionic balance implies "errors" in the quality check between measured conductivity (where $\mathrm{HCO}_{3}{ }^{-}$is included) and the analyzed ions (where $\mathrm{HCO}_{3}{ }^{-}$is excluded). An observed difference between measured and calculated conductivity can also be caused by other not analyzed ions (e.g. formate, acetate, phosphate and in our study also ammonium).

In urban environment dew water composition is thus a function of both long range convected atmosphere and locally produced gas and aerosols. Several studies during the last decades have been concerned with dew chemistry in urban areas, in Santiago, Chile (Ortiz et al., 2000; Rubio et al., 2002, 2006, 2008), in Japan (Yokohama, Osaka, Tokyo) (Okochi et al., 1996, 2008; Takeuchi et al., 2001; Takenaka et al., 2003). Research were also carried out in Poland (Gdansk, Krakow, Wroclaw) (Polkowska et al., 2008), Jordan (Amman) (Jiries, 2001), Israel (Jerusalem) (Berkowicz et al., 2004), Bordeaux (France) (Beysens et al., 2006a), Zadar (Croatia) (Lekouch et al., 2010) and New Delhi (India) (Yadav and Kumar, 2014). The physico-chemical analysis of dew gives information about atmosphere from where it was condensed. The obvious sources of aerosols deposited on the collectors are (i) emissions of hydrocarbons and nitrogen oxides coming from the road traffic, (ii) greenhouse gases and sulfur dioxide coming from nearby industries and house heating in winter, (ii) solid particles coming from the close environment (limestone, ashes of open fires, etc.). Analyses of urban dew usually indicate higher concentration levels of $\mathrm{Ca}^{2+}, \mathrm{SO}_{4}{ }^{2-}$ and $\mathrm{NO}_{3}{ }^{-}$than in rural areas.

The aim of this study is then to determine in the urban environment of the historical center of Paris the volume and occurrence of dew as compared to rain and characterize the main 
chemicals present in dew and rain water. Such studies have not been performed so far to our knowledge in Paris and appear to be a good starting point to compare with further evolution in relation with air quality improvement and urban heat island.

\section{Measurements and methods}

\subsection{Measurement site}

The measurement site is located on an open terrace of the Ecole Supérieure de Physique et Chimie Industrielles ParisTech, $6.8 \mathrm{~m}$ above the ground, with large sky view factor. The site is in the historical center of Paris at the top of a small hill "Montagne Sainte Geneviève" at latitude 48 $50^{\prime}$ '28.24'’ $\mathrm{N}$, longitude $2^{\circ} 20^{\prime} 49.16^{\prime \prime}$ E and $80 \mathrm{~m}$ above sea level (asl). Data have been collected during one year, from 01/04/2011 - 31/03/2012.

Paris metropolitan area presents a relatively flat relief with low elevation (from 28 to $130 \mathrm{~m}$ asl). The climate is temperate and mainly under oceanic influences (Köppen-Geiger climate classification: $\mathrm{Cfb}$ ), with rainy and windy conditions, only infrequently continental. Dispersion of atmospheric pollutants is thus favored. However, the density of population and activities is quite high. Paris and its neighboring agglomeration concentrate about $90 \%$ of the regional population on a little more than $20 \%$ of the region area. According to Air Quality in Europe (2016), the metropolitan area is responsible for more than $75 \%$ of the regional $\mathrm{NO}_{\mathrm{x}}$ emissions, $70 \%$ of the hydrocarbons (volatile organic compounds VOC) and $50 \%$ of the particles. The NOx emissions of the region represent $10 \%$ of the national emissions. The principal sources of pollution are transportation, building heating and industry. Road transportation is responsible for $53 \%$ of the nitrogen oxides $\left(\mathrm{NO}_{\mathrm{x}}\right)$ emissions of the Paris agglomeration, $15 \%$ of the VOC and $25 \%$ of the particles produced by an important fleet of diesel vehicles. Sulfur dioxide seems to be no longer an issue, due to the emission decrease of industrial activities in the region.

\subsection{Dew and rain evaluation}

In the present study, dew is collected on three planar condensers with same yield at $1 \mathrm{~m}$ above the floor of the terrace, facing approximatively SW (220 direction, see Fig. 1). Two reference condensers A and A' are dedicated to automatic volumetric measurements with A' as a spare condenser. Another condenser B is used for chemical sampling. All condensers are tilted with an angle of $30^{\circ}$ with respect to horizontal to collect water by gravity. As noted by Galek et al. 
(2015a), dew collected on plain radiative condensers effectively simulates artificial surfaces found commonly in urban areas, the latter being characterized by low thermal capacity and fast cooling during radiative nights.

Condenser $\mathrm{A}$ is made of a steel sheet of $1.0 \mathrm{~mm}$ thickness, $0.96 \times 0.96 \mathrm{~m}^{2}$ surface area covered with a commercial white painting (ITI Trimetal Steloxine Galva Protect by Akzo Nobel) designed for outdoor use where was added a few \% of radiative hydrophilic mineral additives (0.2-2 $\mu$ m diameter aluminosilicate powder) distributed by OPUR (2016). The sheet is thermally insulated beneath by $22 \mathrm{~mm}$ thickness Styrofam. Water is collected by gravity in a PVC gutter and flow is measured by a pluviometer connected to a weather station. Measurements are taken every min. Air temperature $\left(T_{a}\right)$ was measured with an accuracy of $0.5^{\circ} \mathrm{C}$ with $0.1^{\circ} \mathrm{C}$ resolution; relative humidity ( $\mathrm{RH}$ ) accuracy was $5 \%$ with $1 \%$ resolution, corresponding to $0.9^{\circ} \mathrm{C}$ accuracy and $0.2^{\circ} \mathrm{C}$ resolution in dew point temperature $T_{d}$; wind speed $(V)$ accuracy was $5 \%$ with $0.5 \mathrm{~m} / \mathrm{s}$ stalling speed; wind direction accuracy was $7^{\circ}$ with $1^{\circ}$ resolution. The measurements were performed close to the edge of the building, $7.5 \mathrm{~m}$ above the ground level and about $2 \mathrm{~m}$ above the terrace (Fig. 1).

The calibration of the rain gauge was performed to convert the data in $\mathrm{lm}^{-2}$ (mm) of collected water. The pluviometer was calibrated by gently pouring different volumes of water and measuring the response of the weather station. The conversion ratio mm-condenser/mmstation is $8.51 \times 10^{-3}$. The resolution of water collection is $0.014 \mathrm{~mm}$. Only little dew water remains pinned at the condenser surface (less than 5\% according to Beysens at al., 2007), then the yield is close to a scraped surface.

Condenser A', dedicated to another study, is used as a spare condenser when technical problems occur with condenser A. It is made with $7.5 \mathrm{~mm}$ thick corrugated fibrocement, with surface area $1.52 \times 0.92 \mathrm{~m}^{2}$. Dew water is collected by gravity in a gutter and the corresponding volume is measured by a pluviometer. The resolution of water collection is $0.023 \mathrm{~lm}^{-2}$. The measurements are taken every $15 \mathrm{~min}$. The pluviometer was calibrated by pouring water. The conversion ratio mm-condenser/mm-station is $2.24 \times 10^{-2}$. Due to fibrocement porosity, $0.08 \mathrm{~mm}$ is lost at each event (Doppelt and Beysens, 2013) and has been added to the data for correction. The condenser can be considered as reasonably thermally isolated due to its low thermal conductivity $\left(<0.17 \mathrm{Wm}^{-1} \mathrm{~K}^{-1}\right)$. 
Condenser B is dedicated to chemical studies. It is made of a plastic foil thermally insulated beneath by $22 \mathrm{~mm}$ thickness Styrofam. The foil is $0.35 \mathrm{~mm}$ thickness. It is made with low density polyethylene in which are incorporated a few $\%$ of $\mathrm{TiO}_{2}$ and $\mathrm{BaSO}_{4}$ microsphères and an insoluble surface-active food agent at its surface (similar to Nilsson, 1996; manufactured by OPUR, 2016). The interest of such foil lies in its enhanced dew collection ability and its chemical inert properties. Water runs out by gravity in a PVC gutter and is collected in a polyethylene bottle. The samples are daily collected in the morning at fixed time (about 08:00 local time). The surface of the condenser is scraped to collect the smallest drops pinned at its surface. Dew and rain samples are collected in $50 \mathrm{ml}$ polyethylene bottles without filtering (turbidity of water was generally very low). Volume of water is also measured at the chemistry laboratory when the bottle is not full up (sample lesser than $50 \mathrm{ml}$ ). The minimum volume for performing complete chemical analyzes as mentioned in section 3 is in general 3$5 \mathrm{ml}$. Condenser and scraper are rinsed every day with distilled water. The foil was changed after the first 6 months of utilization, polyethylene being sensitive to UV. The water samples are kept at $3^{\circ} \mathrm{C}$. They are carried out for analysis every 60 days in a refrigerated box to the chemistry laboratory (Laboratory of Hydrology of Aquitaine, University of Bordeaux). The number of analyzed samples was 34 for dew and 77 for rain.

Dew yields were measured primarily from condenser A (34 data), then B from chemical sample volume if absent (16 data) and, if also missing, from A' (13 data).. The distinction between dew, fog and rain is based on morning observation and the evaluation of the water collected rate. Dew rate is much smaller than rain' and cannot be higher than about $10^{-3} \mathrm{~lm}^{-}$ ${ }^{2}$ min. $^{-1}$. For the measurement period (01/04/2011 - 31/03/2012) one reports 63 dew, 5 fog and 146 rain events. Hoarfrost is rare in Paris and such data were not considered. Some measurements were lacking due to technical problems. No angle correction is made for fog and rain when converted in mm; one assumes that the collection area is the condenser surface area. As dew forms during night, daily water data collected on the condenser was chosen to be the sum of hourly data collected between dd-12:00 and dd+1-12:00. Some small uncontrolled bias might then appear when estimating the rain volume for sample collected at 8:00. 




Fig. 1. Condensers (A, A', B) and meteo station (M) on the terrace.

\subsection{Dew yield estimation}

Dew yield can be estimated from meteo data according to an analytical model by Beysens (2016). The model is based on the approximation of a condenser temperature near $T_{d}$ and the recognition that most of the cooling energy is used to maintain the condenser surface at this temperature. The formulation was tested in laboratory and several places in the world with different climates. Agreement within typically 30\% is found with dew measurements. Dew data collected every $15 \mathrm{~min}$. with a condenser of $1 \mathrm{~m}^{2}$ (or similar), inclined at $30^{\circ}$ and thermally insulated from below corresponds to the following amplitude $h_{15}$ (in mm per 15 $\min$.$) :$

$$
\begin{array}{ll}
h_{15}=\frac{0.25}{12}\left[h_{0}-0.06\left(T_{a}-T_{d}\right)\right] & \text { if positive and } V_{10}<V_{0} \\
h=0 & \text { if negative or } V_{10}>V_{0}
\end{array}
$$

The formula under square bracket is dew yield for a $12 \mathrm{~h}$. night. The prefactor $0.25 / 12$ corresponds to rescaling with data taken every $15 \mathrm{~min}$. 
The $2^{\text {nd }}$ term in the square bracket represents a negative contribution due to the condenser heat losses with ambient air, which are proportional to the difference condenser-air temperature $T_{a^{-}}$ $T_{d}$. The conditions about $V_{10}$ (wind speed at $10 \mathrm{~m}$ elevation) correspond to heat losses which become increasingly large above a wind speed threshold $V_{0} \approx 4.4 \mathrm{~m} . \mathrm{s}^{-1}$ where dew cannot form. Wind speed $V_{10}$ can be extrapolated from the measured data according to the classical logarithmic variation (see e.g. Pal Arya, 1988):

$$
V(z)=V_{10} \ln \left(z / z_{c}\right) / \ln \left(10 / z_{c}\right)
$$

The length $\mathrm{z}_{\mathrm{c}}$ (in the present study taken to be $0.1 \mathrm{~m}$ ) is the roughness length, leading to $V_{10} \approx$ $1.1 V$.

The $1^{\text {st }}$ term of Eq. (1), $h_{0}$, is related to the cooling energy divided by the latent heat. Cooling originates from the radiation deficit between condenser and sky due to their different emissivities and varies as $\left(T_{d}+273.15\right)^{4}$ according to the Stefan law. The condenser emissivity is assumed to be close to unity; the sky emissivity is estimated according to Berger et al. (1992); it is a function of site elevation $H(\mathrm{~km})$, dew point temperature $T_{d}$ (in ${ }^{\circ} \mathrm{C}$ ) and cloud coverage $(N$, in oktas) leading to:

$$
\begin{aligned}
h_{0}= & 0.37 \times\left[1+0.204323 H-0.0238893 H^{2}-\left(18.0132-1.04963 H+0.21891 H^{2}\right) \times 10^{-3} T_{d}\right] \\
& \times\left(\frac{T_{d}+273.15}{285}\right)^{4}(1-N / 8)
\end{aligned}
$$

The cloud coverage has been estimated from interpolating at 15 min. frequency data taken every 3h. at the airport meteo station Paris-Orly $(12 \mathrm{~km})$ from the Paris measurement site.

The daily dew yield $h$ (mm/day) is the daily sum of the $h_{15}$, taken every $15 \mathrm{~min}$.: 


$$
h=\sum_{\mathrm{dd}: 12: 00}^{\mathrm{dd}+1: 11: 45}
$$

The data obtained during daylight are automatically discarded in the calculation because of the too large difference in $T_{a}-T_{d}$, making $h_{15}$ negative.

\section{Results and discussion}

The following analyses were carried out: $\mathrm{pH}$, electric conductivity (EC), chemical analysis for major cations $\left(\mathrm{Na}^{+}, \mathrm{K}^{+}, \mathrm{Ca}^{2+}\right.$ and $\left.\mathrm{Mg}^{2+}\right)$ and major anions $\left(\mathrm{Cl}^{-}, \mathrm{SO}_{4}{ }^{2-}\right.$ and $\left.\mathrm{NO}_{3}{ }^{-}\right)$and minor ions $\left(\mathrm{Fe}^{2+}, \mathrm{Cu}^{2+}, \mathrm{Cd}^{2+}, \mathrm{Mn}^{2+}, \mathrm{Pb}^{2+}, \mathrm{Zn}^{2+}, \mathrm{NO}_{2}^{-}, \mathrm{Br}^{-}, \mathrm{F}\right)$. Inductively coupled plasma mass spectrometry (ICP-MS) was available for the determination of cations while ion chromatography was used for analyzing the anions. Unfortunately no analyses of ammonium were performed (see the discussion in section 3.4).

Many distributions of trace species coming from natural processes are strongly asymmetric, but they could be symmetrized by a lognormal distribution. The approximated location of the center of the frequency distribution can be determined by different measures. The most common is the arithmetic mean, but very susceptible to high values, especially with small amounts of samples. The median, that is the value being on the middle digit, is more appropriate. The Paris dew and rain data show strong right-skewed (lognormal like) distributions. The median is thus mostly significant smaller than the arithmetic mean. Very similar to the median is the volume weighted mean (VWM) which takes into account the effect of dilution by the dew or rain water amount and is useful in comparative studies. It can be calculated from

$$
\mathrm{VWM}=\frac{\sum_{i=1}^{N} v_{i}\left[\mathrm{X}_{\mathrm{i}}\right]}{\sum_{i=1}^{N} v_{i}}
$$

where $\left[\mathrm{X}_{\mathrm{i}}\right]$ is the concentration of ion $\mathrm{X}$ and $v_{i}$ is the water sample volume.

The analysis of correlations between two or several random variables can be performed by the calculation of their coefficient of correlation. This coefficient, the Pearson product-moment correlation coefficient $r$, is equal to the ratio of their covariance with the non-null product of their standard deviations. The coefficient $r$ is a measure of the linear correlation between two variables X and Y. According to Chok (2008), this coefficient can be successfully used for analysis of non-normally distributed data as frequently found in this study. 


\subsection{Dew and rain yields}

Daily dew and rain data and their summation data are presented on Fig. 2 and the statistics are summarized in Table 1. Dew yield is the largest in fall, with however a remarkable peak in summer. Both periods experienced a quite sunny period, corresponding to clear nocturnal sky. The yearly yield $(3.48 \mathrm{~mm}$ ) is low although the sky view factor is large, due presumably to higher temperatures than in Paris neighborhood. As there are no recorded dew data available, no comparison can be made with other years. However, a detailed discussion with comparison of calculated dew yields in Paris and nearby at Paris-Orly airport is given below at the end of the section.

Concerning rain, important rain storms were observed in August. Rain data can be compared to data collected every $3 \mathrm{~h}$. at the airport meteo station Paris-Orly, located within $12 \mathrm{~km}$ from the dew measurement site. The number of rainy days in Paris (146) is more important than in Paris-Orly (107) because the detection threshold in Paris-Orly $(0.2 \mathrm{~mm})$ is higher than in Paris (0.004 mm). However, the maximum daily rain amounts are close (Paris: $4.1 \mathrm{~mm}$; Paris-Orly: $5.02 \mathrm{~mm}$ ) as the yearly sum (Paris: $593 \mathrm{~mm}$; Paris-Orly: $547 \mathrm{~mm}$ ), the somewhat higher yield in Paris being presumably due to the recording of smaller event, corresponding to the smaller detection level. The values found are less but comparable to a 30 years average (1981-2010, see meteo-France, 2016): $637.4 \mathrm{~mm}$ annual rainfall, 111.1 rainy days. Note that fall 2011 was one of the hottest falls since meteorological measurements are carried out in Paris.

The data collected on site and those calculated with Eq. 4 are reported in Table 1 and in Fig. 2c where are shown the evolution of measured and calculated cumulated dew values. The numbers of dew days are comparable (measured: 63; calculated: 74), the maximum yields also (measured: 0.19; calculated: 0.17). The yearly sums only differ by $30 \%$ (measured: 3.48 mm; calculated: $2.35 \mathrm{~mm}$ ). However, the calculated data evolution does not fit very well the experimental evolution. The main differences are due to the November (and to lesser extent, August) events, which are not properly taken into account in the model. Cloud cover in downtown Paris is also often smaller than in its suburb. We thus imposed the arbitrary lower mean value ( $N-1)$, which indeed gives a better agreement (Fig. 2c).

It is interesting to compare the calculated dew yields in Paris center and Paris-Orly. The results are reported in Table 1. The number of dew events (196) is more than two times higher than in Paris (74), the maximum yield also (Paris-Orly: $0.37 \mathrm{~mm}$; Paris: $0.17 \mathrm{~mm}$ ) and the annual yield is 5 times higher (Paris-Orly: $17.11 \mathrm{~mm}$; Paris: $2.35 \mathrm{~mm}$ ). This difference cannot 
be attributed to cloud coverage deviations that lead to a 30\% difference nor the sky view factor (however crucial in many urban locations as stressed by Richards, 2002, 2005). It is rather the result of warmer and dryer downtown air (Ye, 2007; Muskała, 2015) thanks to the so-called urban heat island (see Glossary of Meteorology, 2009). In Paris, the urban/rural gap is found between 1 and $6 \mathrm{~K}$ and its average for the 10 years 1990-1999 is $3.3 \mathrm{~K}$ (Cantat, 2004). The contrast is particularly noticeable at night. As a matter of fact, the nightly (21:00 06:00) yearly mean is $\overline{T_{a}}=12.9 \mathrm{~K}$ in downtown Paris and $10.3 \mathrm{~K}$ in Paris-Orly, whereas the dew point temperature is only slightly depressed with $\overline{T_{d}}=7.7 \mathrm{~K}$ in downtown Paris and 7.2 $\mathrm{K}$ in Paris-Orly. The mean difference $\overline{T_{a}-T_{d}}=5.30 \mathrm{~K}$ in downtown Paris and $3.15 \mathrm{~K}$ in Paris-Orly thus exhibits a large dissimilarity, which explains the difference in dew yields.
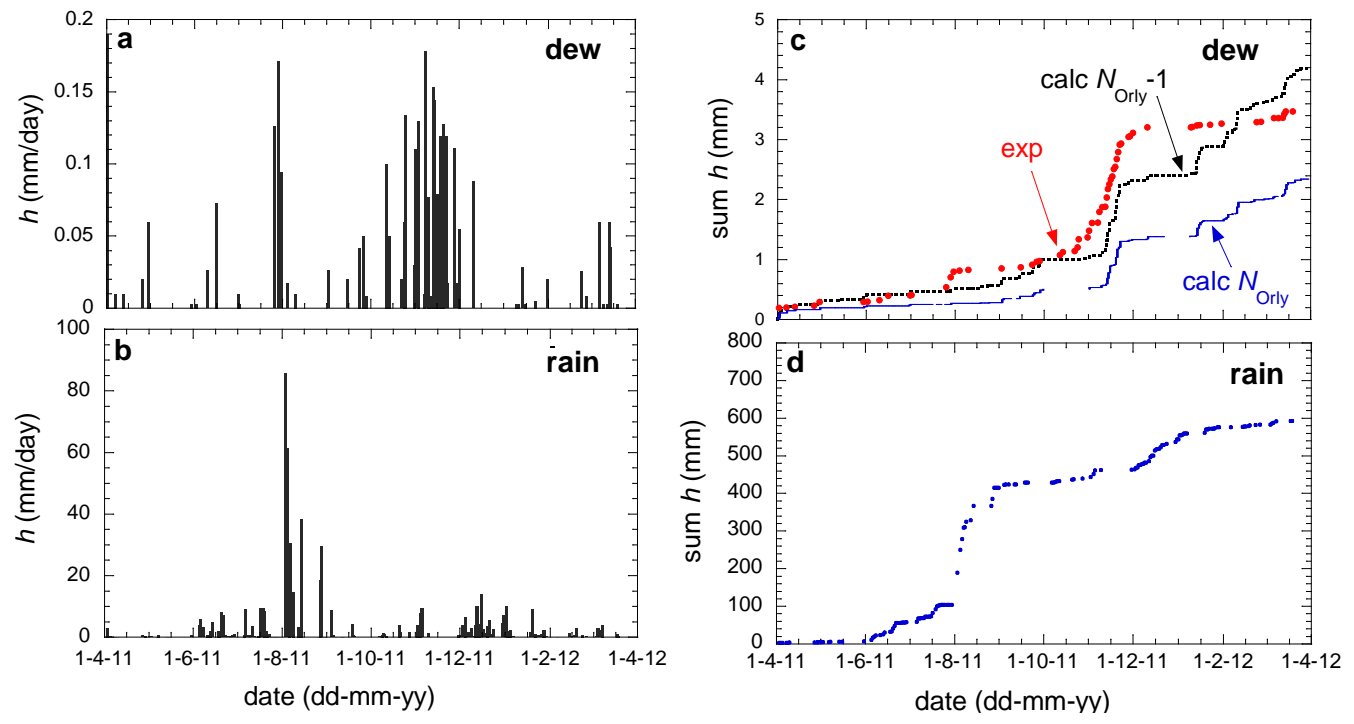

Fig. 2. One year evolution of (a) dew and (b) rain yield (in $\mathrm{lm}^{-2}$ or mm). (c): Summation of daily dew from experimental data and from calculated data using Eq. 4 and cloud coverage $N_{\text {Orly }}$ (in oktas) as measured in Paris-Orly. Another calculation where the cloud cover $N_{\text {Orly }}-1$ is used instead of $N$ is shown for sake of comparison (see text). (d): Summation of the rain daily data shown in (b). 


\begin{tabular}{c||c|c|c||c|c}
$\begin{array}{c}\text { Measurement } \\
(\mathrm{mm})\end{array}$ & $\begin{array}{c}\text { Dew } \\
\text { meas. } \\
\text { Paris }\end{array}$ & $\begin{array}{c}\text { Dew } \\
\text { calc. } \\
\text { Paris }\end{array}$ & $\begin{array}{c}\text { Dew calc. } \\
\text { Paris-Orly }\end{array}$ & $\begin{array}{c}\text { Rain } \\
\text { meas. } \\
\text { Paris }\end{array}$ & $\begin{array}{c}\text { Rain } \\
\text { meas. } \\
\text { Paris- } \\
\text { Orly }\end{array}$ \\
\hline \hline Nb. daily events & 63 & 74 & 196 & 146 & 107 \\
\hline$h_{\min }(\mathrm{mm} /$ day $)$ & 0.003 & $1.6 \times 10^{-4}$ & $1.6 \times 10^{-4}$ & 0.0046 & 0.2 \\
\hline$h_{\max }(\mathrm{mm} /$ day $)$ & 0.19 & 0.17 & 0.37 & 86 & 29 \\
\hline$h_{\text {mean }}(\mathrm{mm} /$ day $)$ & 0.055 & 0.032 & 0.087 & 4.1 & 5.02 \\
\hline Yearly sum $h(\mathrm{~mm})$ & 3.48 & 2.35 & 17.11 & 593 & 547
\end{tabular}

Table 1. Dew and rain characteristics at Paris (01/04/2011 - 31/03/2012).

\section{2. $\mathrm{pH}$ measurements}

The analytical results for dew and rain are shown in Tables 2 and 3, respectively. Beside arithmetic means, median, minimum and maximum values, volume weighted means (VWM) are also given.

To calculate arithmetic and volume weighted means of the $\mathrm{pH}$, the $\mathrm{pH}$ values is firstly converted to $\mathrm{H}^{+}$concentrations $\left(\left[\mathrm{H}^{+}\right]=10^{-\mathrm{pH}+3}\right.$ (in $\mathrm{mg} / \mathrm{l}$ ). The calculated values are then converted back to $\mathrm{pH}$ units $(\mathrm{pH}=-\log [\mathrm{H}+]+3)$. $\mathrm{pH}$ arithmetic averages and VWM differ weakly for both dew and rain samples.

Dew $\mathrm{pH}$ variations are large, with values ranging between 5.3 and 10.5. The volume weighted mean was calculated to be 6.5. The median is at 6.7. Similar large variations are observed for rain $\mathrm{pH}$ that shows values close to dew's, ranging between 5.1 and 10.6 with a VWM of 6.1 and a median of 6.5. No seasonal variations are observed within the scatter of data, see Fig. 3. No visible $\left[\mathrm{H}^{+}\right]$dependence on dew and rain volume can be observed either. The differences between dew and rain $\mathrm{pH}$ values are small (Tables 2-3, Fig. 3), Paris rain being slightly more acidic than dew. This corresponds to the results found in some other urban areas as well as at humid sites (Xu et al., 2015).

Near-neutral $\mathrm{pH}$ values in dew and rain are caused by the neutralization of acidity and buffering by the alkaline elements of soil, dust and sea salt origin. This neutralization is confirmed by a strong correlation between the acidic ions $\left(\mathrm{SO}_{4}{ }^{2-}\right.$ and $\left.\mathrm{NO}_{3}{ }^{-}\right)$and the major cations $\left(\mathrm{Ca}^{2+}\right.$ and $\left.\mathrm{Mg}^{2+}\right)$ (see Tables 2-3 and section 3.7). 


\begin{tabular}{|c|c|c|c|c|c|c|c|}
\hline Dew & $N$ & $\begin{array}{l}\text { vol. weighted } \\
\text { mean (VWM) }\end{array}$ & $\begin{array}{c}\text { arithmetic } \\
\text { mean }\end{array}$ & $\min$. & median & max. & $\begin{array}{l}\text { WHO } \\
\text { mean }\end{array}$ \\
\hline " Vol (ml) & 34 & 64 & 64 & 5 & 50 & 190 & \\
\hline $\mathrm{H}^{+}\left(\mathrm{mM} / \mathrm{l} \times 10^{4}\right)$ & 34 & 3.3 & 4.1 & 0.00031 & 1.8 & 50 & \\
\hline \multicolumn{8}{|l|}{$\begin{array}{l}\text { Cations (mg/l) } \\
\end{array}$} \\
\hline $\mathrm{Na}^{+}$ & 34 & 5.9 & 8.0 & 0.8 & 6 & 45.6 & 200 \\
\hline$=\mathrm{K}^{+}$ & 34 & 1.7 & 2.8 & 0.4 & 1.9 & 17 & \\
\hline$\stackrel{\stackrel{0}{\Xi} \mathrm{Ca}^{2+}}{ }$ & 34 & 12.4 & 19 & 1 & 14 & 61 & \\
\hline$\sum \mathrm{Mg}^{2+}$ & 34 & 0.7 & 1.1 & 0 & 0.8 & 5.6 & \\
\hline $\mathrm{Fe}^{2+}$ & 34 & 0.007 & 0.042 & 0.003 & 0.01 & 0.2 & \\
\hline $\mathrm{Cu}^{2+}$ & 34 & 0.013 & 0.019 & 0.005 & 0.015 & 0.055 & 2 \\
\hline$\stackrel{\mathrm{Cd}^{2+}}{ }$ & 34 & 0.001 & 0.001 & 0.001 & 0.001 & 0.001 & 3 \\
\hline $\mathrm{Mn}^{2+}$ & 34 & 0.008 & 0.013 & 0.002 & 0.01 & 0.04 & 0.4 \\
\hline $\mathrm{Pb}^{2+}$ & \begin{tabular}{|l|}
34 \\
\end{tabular} & 0.001 & 0.01 & 0.005 & 0.009 & 0.002 & 0.01 \\
\hline $\mathrm{Zn}^{2+}$ & 34 & 0.063 & 0.1 & 0.005 & 0.0045 & 0.48 & \\
\hline \multicolumn{8}{|l|}{ Anions (mg/l) } \\
\hline \begin{tabular}{l|l}
\multirow{2}{*}{$\mathrm{Cl}^{-}$} \\
$\mathrm{n}$
\end{tabular} & 34 & 8.9 & 14.2 & 0.5 & 7.7 & 82 & 250 \\
\hline 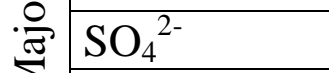 & 34 & 19.9 & 25.2 & 2 & 23.6 & 93 & 250 \\
\hline$\sum \mathrm{NO}_{3}^{-}$ & 34 & 11.8 & 14.7 & 0.1 & 8.4 & 64 & 50 \\
\hline$=\mathrm{NO}_{2}^{-}$ & 34 & 1.2 & 0.9 & 0 & 0 & 8.4 & 50 \\
\hline$\stackrel{\mathrm{Br}^{-}}{ }$ & 34 & 0.018 & 0.02 & 0 & 0.01 & 0.15 & \\
\hline$\sum \mathrm{F}^{-}$ & 34 & 0.077 & 0.1 & 0 & 0.08 & 0.7 & 1.5 \\
\hline $\begin{array}{l}\mathrm{pH} \\
\end{array}$ & 34 & 6.5 & 6.4 & 5.3 & 6.74 & 10.5 & 9.5 \\
\hline $\begin{array}{l}\text { EC }\left(25^{\circ} \mathrm{C},\right. \\
\mu \mathrm{S} / \mathrm{cm})\end{array}$ & 34 & 124 & 156 & 26 & 118 & 478 & 2500 \\
\hline $\mathrm{EC}_{\text {calc }}$ & 34 & 122 & 151 & 20 & 115 & 463 & \\
\hline  & 34 & 0.98 & 1.46 & 0.14 & 1.0 & 4.7 & \\
\hline Eanions (meq/l) & 34 & 0.85 & 1.16 & 0.15 & 0.86 & 3.4 & \\
\hline TIC (meq/l) & 34 & $\begin{array}{l}1.8 \\
\end{array}$ & 2.6 & 0.3 & $\overline{2}$ & 8 & \\
\hline
\end{tabular}

Table 2: Dew ion concentration statistics. $N$ is the number of analyzed samples. When minimum concentration is zero, detection threshold is indicated as a substitute. Summed (total) volume is $2185 \mathrm{ml}$ ). 


\begin{tabular}{|c|c|c|c|c|c|c|c|}
\hline Rain & $N$ & $\begin{array}{l}\text { vol. weighted } \\
\text { mean (VWM) }\end{array}$ & $\begin{array}{c}\text { arithm. } \\
\text { mean }\end{array}$ & $\min$. & median & max. & $\begin{array}{l}\text { WHO } \\
\text { mean }\end{array}$ \\
\hline Vol (ml) & 77 & 4249 & 4249 & 5 & 850 & 85600 & \\
\hline $\mathrm{H}^{+}\left(\mathrm{mM} / \mathrm{l} \times 10^{4}\right)$ & 77 & 8.42 & 7.76 & 0.00025 & 3.2 & 89 & \\
\hline \multicolumn{8}{|l|}{$\begin{array}{l}\text { Cations (mg/l) } \\
\end{array}$} \\
\hline $\mathrm{Na}^{+}$ & 77 & 1.1 & 3.8 & 0.1 & 1.4 & 81.5 & 200 \\
\hline $\mathrm{K}^{+}$ & 77 & 0.68 & 1.0 & 0.1 & 0.8 & 16 & \\
\hline $\mathrm{Ca}^{2+}$ & 77 & 3.05 & 4.2 & 0.2 & 2 & 43 & \\
\hline$\sum \mathrm{Mg}^{2+}$ & 77 & 0.17 & 0.4 & 0.005 & 0.02 & 0.17 & \\
\hline $\mathrm{Fe}^{2+}$ & 77 & 0.03 & 0.03 & 0.005 & 0.01 & 0.18 & \\
\hline $\mathrm{Cu}^{2+}$ & 77 & 0.0024 & 0.01 & 0.002 & 0.005 & 0.04 & 2 \\
\hline $\mathrm{Cd}^{2+}$ & 77 & 0.001 & 0.001 & 0.001 & 0.001 & 0.001 & 3 \\
\hline$\sum \mathrm{Mn}^{2+}$ & 77 & 0.0008 & 0.01 & 0.003 & 0.005 & 0.03 & 0.4 \\
\hline $\mathrm{Pb}^{2+}$ & 77 & 0.00022 & 0.007 & 0.005 & 0.008 & 0.008 & 0.01 \\
\hline $\mathrm{Zn}^{2+}$ & 77 & 0.035 & 0.06 & 0.005 & 0.04 & 0.49 & \\
\hline \multicolumn{8}{|l|}{ Anions (mg/l) } \\
\hline$=\mathrm{Cl}^{-}$ & 77 & 2.6 & 7 & 0 & 2.5 & 140 & 250 \\
\hline $\mathrm{SO}_{4}^{2-}$ & 77 & 3.7 & 5.4 & 0.2 & 3 & 65 & 250 \\
\hline$\sum \mathrm{NO}_{3}^{-}$ & 77 & 4.1 & 4.5 & 0.1 & 2 & 38 & 50 \\
\hline \begin{tabular}{l|l} 
& $\mathrm{NO}_{2}^{-}$ \\
\end{tabular} & 45 & 0.06 & 0.09 & 0.01 & 0.04 & 0.33 & 50 \\
\hline$\stackrel{\mathrm{Br}^{-}}{ }$ & 45 & 0.03 & 0.016 & 0.01 & 0.03 & 0.08 & \\
\hline $\begin{array}{l}\Sigma \mathrm{F}^{-} \\
\end{array}$ & 45 & 0.06 & 0.02 & 0.01 & 0.04 & 0.33 & 1.5 \\
\hline $\begin{array}{l}\mathrm{pH} \\
\end{array}$ & 77 & 6,1 & 6.1 & 5.1 & $6.5^{\mathrm{c}}$ & 10.6 & 9.5 \\
\hline $\begin{array}{l}\text { EC }\left(25^{\circ} \mathrm{C},\right. \\
\mu \mathrm{S} / \mathrm{cm})\end{array}$ & 77 & 35 & 59.6 & 2.7 & 40 & 810 & 2500 \\
\hline $\mathrm{EC}_{\text {calc }}$ & 77 & 29 & 57 & 2 & 35 & 750 & \\
\hline Ecations (meq/l) & 77 & 0.23 & 0.45 & 0.02 & 0.28 & 5.8 & \\
\hline Eanions (meq/l) & 77 & 0.22 & 0.38 & 0.01 & 0.25 & 5.6 & \\
\hline TIC (meq/l) & 77 & 0.45 & 0.86 & 0.03 & 0.5 & 11 & \\
\hline
\end{tabular}

Table 3. Rain ion concentration statistics. $N$ is the number of analyzed samples. When minimum concentration is zero, detection threshold is indicated as a substitute. Summed (total) volume is $327185 \mathrm{ml}$. 




Fig. 3. Dew pH (full circles) and rain (open squares) evolution. The lines are volume weighted mean values (VWM ) and median values (from Tables 2-3).

\subsection{Conductivity measurements}

Dew electric conductivity EC (Tables 2-3) takes values in the study period between $26 \mu \mathrm{S} / \mathrm{cm}$ and $478 \mu \mathrm{S} / \mathrm{cm}$. Volume weighted means, calculated by Eq. 5, is $124 \mu \mathrm{S} / \mathrm{cm}$. Rain EC values extend from $2.7 \mu \mathrm{S} / \mathrm{cm}$ to $810 \mu \mathrm{S} / \mathrm{cm}$ with a volume weighted mean of $35 \mu \mathrm{S} / \mathrm{cm}$. One notes that the dew EC mean value is rather large when compared to other studied urban locations in the world, meaning large total dissolved solids TDS (Lekouch et al., 2011; Tomaszkiewicz, 2015).

Total dissolved solids can be approximated by the formula TDS $=k_{e}$ EC, with TDS in mg/l and $\mathrm{EC}$ in $\mu \mathrm{S} / \mathrm{cm}$ at $25^{\circ} \mathrm{C}$ (Atekwana et al., 2004). The correlation factor $k_{e}$ varies between 0.55 and 0.8. Taking the mean value $k_{e} \approx 0.7$ it comes for dew about (volume weighted) 87 $\mathrm{mg} / \mathrm{l}$. For rain TDS is about (volume weighted) $24 \mathrm{mg} / \mathrm{l}$, that is, 3.5 times less than dew TDS. The mean EC and TDS in dew are both higher than those in rain samples, reflecting thus higher total dissolved ions in dew.

Figure 4 reports the evolution for both dew and rain EC. Seasonal variations (if any) are less than the scatter of data. In Fig. 5 is shown the sample volume dependence of EC. Despite the 
scatter of data there is a trend to have less conductivity with large volume, corresponding to the increased dilution of adsorbed gas and aerosols particles. The effect should be $\sim 1 / h$, corresponding to data showing a slope -1 when in a log-log plot. Insets of Fig. 5 indeed show such a tendency. A fit of the data to $\mathrm{EC}=\alpha h^{-1}$ gives (dew) $\alpha=4.6 \pm 0.8, \mathrm{r}=0.58$ and (rain) $\alpha=7 \pm 2, \mathrm{r}=0.45$ (uncertainties: one standard deviation). The fact that data are much scattered simply reflects that, in addition to the dilution effect, ion concentration also vary according to the different events.



Fig. 4. Dew (full circles) and rain (open squares) EC evolution (semi-log plot). 

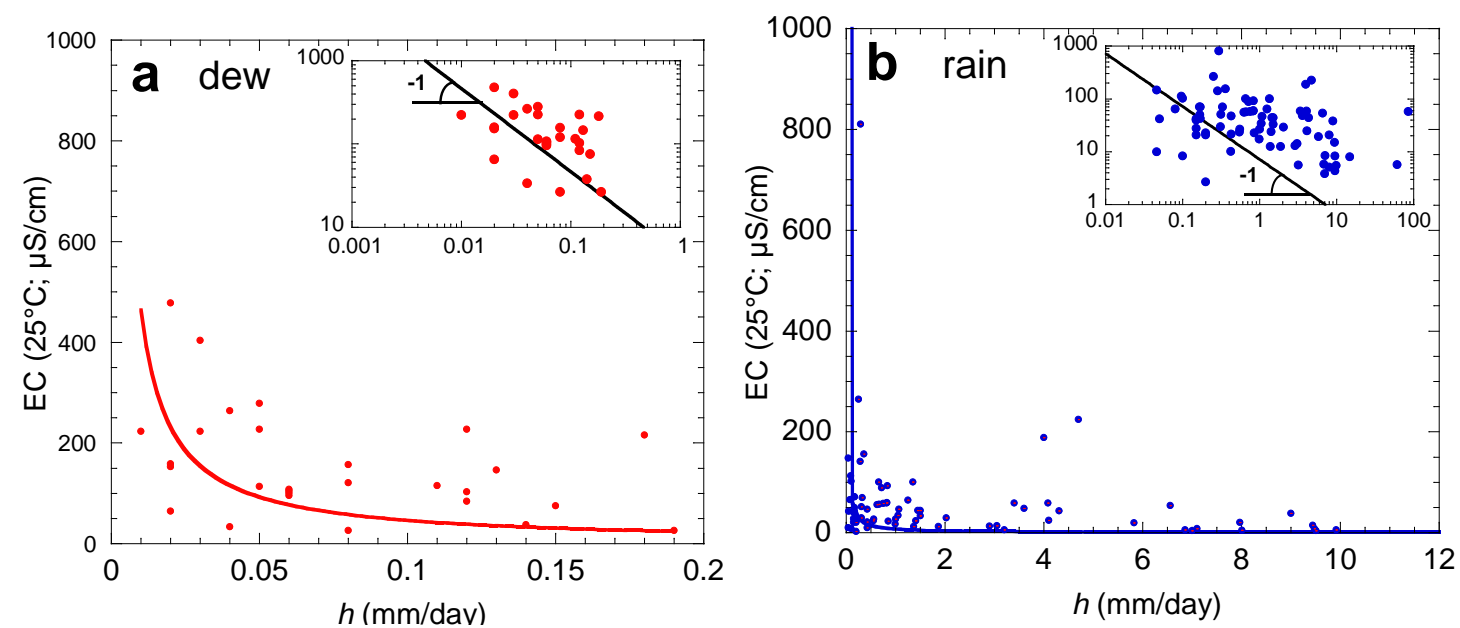

Fig. 5. Variation of electrical conductivity EC with nightly condensed volume $h$ ( $\mathrm{mm} /$ day). The lines are fits to $\mathrm{EC}=\alpha h^{-1}$ (see text). (a) dew; (b) rain (two data are out of axes). Insets: log-log plots showing dilution dependence (line with slope -1 , see text).

\subsection{Ion concentrations}

Data quality assurance was performed by evaluating (see Tables 2-3) the percentage difference of the ionic balance

$$
\text { BAL } \%=100 \times\left[\left(\sum \text { cation }-\sum \text { anion }\right) /\left(\sum \text { cation }+ \text { Sanion }\right)\right] \text {, }
$$

with

$$
\begin{aligned}
& \sum \text { cations }=\left[\mathrm{Na}^{+}\right]+\left[\mathrm{K}^{+}\right]+\left[\mathrm{Ca}^{2+}\right]+\left[\mathrm{Mg}^{2+}\right]+\left[\left[\mathrm{H}^{+}\right]\right. \\
& \sum \text { anions }=\left[\mathrm{Cl}^{-}\right]+\left[\mathrm{SO}_{4}{ }^{2-}\right]+\left[\mathrm{NO}_{3}{ }^{-}\right] .
\end{aligned}
$$

Comparison is also made with the measured and calculated conductivities,

$$
\Delta \mathrm{EC}=100 \times\left(\mathrm{EC}_{\mathrm{c}}-\mathrm{EC}\right) /(\mathrm{EC})
$$

$\mathrm{EC}_{\mathrm{c}}$ is the calculated conductivity according to $\mathrm{EC}_{\mathrm{c}}=$ $50.1\left[\mathrm{Na}^{+}\right]+73.5[\mathrm{~K}]+53\left[\mathrm{Mg}^{2+}\right]+59.5\left[\mathrm{Ca}^{2+}\right]+349.7\left[\mathrm{H}^{+}\right]+76.4\left[\mathrm{Cl}^{-}\right]+80.8\left[\mathrm{SO}_{4}{ }^{2-}\right]+71.4\left[\mathrm{NO}_{3}{ }^{-}\right]$. The acceptability criterion is set as $\leq \pm 20 \%$ to comply with the requirements of the Global Atmosphere Watch Program for precipitation chemistry (World meteorological organization 
global atmosphere watch, 2004). As seen in Fig. 6, linear fits are observed for dew and rain data between $\Sigma$ cations and $\Sigma$ anions. In addition, linear fits are found between EC and $\mathrm{EC}_{\mathrm{c}}$ : $\mathrm{EC}=0+1.017 \times \mathrm{EC}_{\mathrm{c}}$ with $\mathrm{r}=0.99(\mathrm{dew})$ and $\mathrm{EC}=3.14+1.039 \times \mathrm{EC}_{\mathrm{c}}$ with $\mathrm{r}=0.99$ (rain).

A nearly equalized balance is highly valuable but is not a strong evidence for a true or complete analysis. Errors may compensate each other in data quality and even more in missing ionic species. The ions which unfortunately were not measured during our study (for example: $\mathrm{NH}^{4+}$ and $\mathrm{HCO}_{3}{ }^{-}$) should contribute in the physico-chemical analysis. Ammonium is a fragile ion and the period of time between sampling and analysis could possibly be not short enough to avoid any oxidation reactions.

Several studies in Central Europe (e.g., Buijsman and Erisman, 1988; vanLoon and Duffy (2011), Galek et al. 2015b) or in India (Yadav and Kumar 2014) suggest that such ions should not be neglected. In urban environment, on average $\mathrm{NH}_{4}{ }^{+}$concentrations of $0.010-0.080 \mathrm{meq} / \mathrm{l}$ were observed in rain water compared to $0.002-0.004 \mathrm{meq} / \mathrm{l}$ at stations influenced to negligible extent by human activity. The special and temporal variation of pollutants in precipitation at 37 more or less rural stations in France was investigated from three different monitoring networks within more than 10 years (1995-2007) by Pascaud et al. (2016). At several stations located in western and northern areas a decrease of $\mathrm{NH}_{4}{ }^{+}$concentration in atmospheric deposition was observed while the estimates of $\mathrm{NH}_{3}$ emissions remained fairly stable. When considering all the sampling sites, the volume-weighted mean concentration of $\mathrm{NH}_{4}{ }^{+}$was $0.028 \mathrm{meq} / \mathrm{l}$ (ranging from 0.013 to 0.046 meq/1).

For dew water mean values from 0.05 meq/l (Alebić-Juretić and Sojat, 1998) and even 0.25 meq/l (Polkowska et al., 2008) were found. Yadav and Kumar (2014) found that in Delhi ammonium plays a dominant role in the acidity neutralization of dew and rain.

In our study the difference in the total concentrations of measured positive and negative charge balance is very low. One could thus speculate that ammonium plays a minor role as neutralizing component in rain and dew water in Paris as compared to the non-sea-salt base cations concentration, which contributes within about $40 \%$ to the TIC. 



Fig. 6. Electrical neutrality. Sum of major anions $\left(\mathrm{Na}^{+}, \mathrm{K}^{+}, \mathrm{Ca}^{+}, \mathrm{Mg}^{2+}, \mathrm{H}^{+}\right)$versus sum of major cations $\left(\mathrm{Cl}^{-}, \mathrm{SO}^{2-} \mathrm{NO}_{3}{ }^{-}\right)$on a log-log plot. Lines are fits to $\Sigma$ cations $=\beta$ Eanions, with $\beta$ a proportionality constant expected to be unity. (a): Dew. The interrupted line is a fit to all data ( $\beta=0.80 \pm 0.04$, uncertainty is one standard deviation, $\mathrm{r}=0.91$ ). The dotted line corresponds to a fit where 5 data have been removed because of very low collected volumes. It gives $\beta=0.88 \pm 0.02, \mathrm{r}=0.97$. (b): rain. The interrupted line is a fit to all data ( $\beta=1.05 \pm 0.02$, uncertainty is one standard deviation, $\mathrm{r}=0.98$ ).

Tables 2 and 3 also summarizes the mean, maximum and minimal chemical compositions of dew and rain events in the period of study. Mean concentrations are volume weighted as for $\left[\mathrm{H}^{+}\right]$, see Eq. 5. The detectability threshold is 0.001 or $0.005 \mathrm{mg} / \mathrm{l}$, depending on ions. Only data above the detectability threshold have been analyzed.

The minor ions (iron, copper, cadmium, manganese, lead, zinc, lead, nitite, brominate, fluorine) are in small quantity in both dew and rain water. In rain water, nitrite is quite low, with only 11 data above the detection level. As usual, nitrite concentration is somewhat higher for dew samples, due to its formation mainly by heterogeneous gas reactions occurring on wetted surfaces (Alicke et al., 2003; Acker et al., 2005, 2008). Lead, usually caused by the road traffic, exhibits a small value, corresponding to the removal of lead in car fuels.

The distribution of major ions in both rain and dew are similar, with (dew and rain) $\mathrm{Ca}^{2+}>$ $\mathrm{Na}^{+}>\mathrm{K}^{+}>\mathrm{Mg}^{2+}$ and (dew) $\mathrm{SO}^{2-}>\mathrm{NO}^{-}>\mathrm{Cl}^{-}$and (rain) $\mathrm{SO}^{2-} \approx \mathrm{NO}^{-}>\mathrm{Cl}^{-}$. However, ion concentrations in dew are about 4 times higher than in rain, in agreement with the calculation of TDS from the EC's as performed above in section 3.3 where a factor 3.5 is found. 
The dominant cation in both dew and rain is $\mathrm{Ca}^{2+}$. Its probable source is dust of the ground suspended in the low layers of the atmosphere but also the particles of the surrounding medium brought to the surface of the condenser by the wind. The main source of $\mathrm{Ca}^{2+}$ is the abrasion of streets and sidewalks, weathering of plasters as well as building activities (Polkowska et al., 2008). Ions $\mathrm{Na}^{+}$and $\mathrm{Mg}^{2+}$ are from marine origin, due to the strong oceanic influence in Paris (180 km from the ocean), as is also discussed below in section 3.6. The origin of potassium can be found in the presence of large agricultural areas around Paris.

Ions $\mathrm{SO}_{4}{ }^{2-}$ and $\mathrm{NO}_{3}{ }^{-}$reveals pollution in dew and rain, coming from the local urban anthropogenic contributions. Sulfate, beyond the marine contribution (see below section 3.6), is of anthropogenic origin (combustion of sulfated fossil fuels), alike nitrates (road traffic).

Chloride is from marine origin (see below section 3.6).

It is interesting to note in Tables 2-3 that the chemical composition of Paris dew and rain urban water generally meets the WHO requirements. Although there is no requirements for $\mathrm{pH}$ (WHO pH revised, 2007), we have retained a current recommendation $\mathrm{pH}<9.5$. Only very rare data exceeded the WHO requirements. For dew, one notices two $\mathrm{NO}_{3}{ }^{-}$data and one $\mathrm{pH}$ data. For rain, two $\mathrm{pH}$ data are out of the requirements. Even the lead concentration keeps below the maximum recommended.

\subsection{Correlation anions-cations}

The correlation between ions in dew and rain are presented in Table 4. The analysis of these correlations highlights the possible relations between two or several random variables. A measurement of this correlation is obtained by the calculation of their coefficient of correlation, $r$ (see section 3), which is a measure of the linear correlation between two variables X and Y. According to Chok (2008), this coefficient can be successfully used for analysis of non-normally distributed data. Then Table 4 data indeed represents a measurement of the goodness of linear correlation. The coefficient of correlation lies between -1 and 1 :

$$
r=\frac{\sum_{i=1}^{N}\left(x_{i}-\bar{x}\right) \cdot\left(y_{i}-\bar{y}\right)}{\sqrt{\sum_{i=1}^{N}\left(x_{i}-\bar{x}\right)^{2}} \cdot \sqrt{\sum_{i=1}^{N}\left(y_{i}-\bar{y}\right)^{2}}}
$$


The results are listed in Table 4.

\begin{tabular}{|c|c|c|c|c|c|c|c|c|c|c|c|}
\hline Rain Dew & $\mathrm{Ca}^{++}$ & $\mathrm{Na}^{+}$ & $\kappa^{+}$ & $\mathrm{Mg}^{++}$ & $\mathrm{SO}_{4}^{-{ }^{-}}$ & $\mathrm{NO}_{3}^{-}$ & $\mathrm{Cl}^{-}$ & $\mathrm{Zn}^{++}$ & $\mathrm{Fe}^{++}$ & $\mathrm{Cu}^{++}$ & $\mathrm{Pb}^{+}$ \\
\hline $\mathrm{Ca}^{++}$ & & 0.43 & 0.74 & 0.61 & 0.78 & 0.52 & 0.46 & 0.28 & 0.27 & 0.51 & 0.02 \\
\hline $\mathrm{Na}^{+}$ & 0.75 & . & 0.47 & 0.91 & 0.41 & 0.21 & $\underline{0.92}$ & -0.01 & 0.10 & 0.26 & 0.08 \\
\hline $\mathrm{K}^{+}$ & 0.04 & 0.10 &  & 0.69 & 0.69 & 0.26 & 0.55 & -0.02 & 0.36 & 0.17 & -0.03 \\
\hline $\mathrm{Mg}^{+}$ & 0.47 & 0.49 & 0.20 & & 0.53 & 0.21 & $\underline{0.94}$ & 0.06 & 0.30 & 0.32 & 0.13 \\
\hline $\mathrm{SO}_{4}^{-}$ & $\underline{0.93}$ & $\underline{0.91}$ & 0.07 & 0.49 & & 0.76 & $\overline{0.87}$ & 0.16 & 0.32 & 0.40 & 0.17 \\
\hline $\mathrm{NO}_{3}^{-}$ & 0.73 & 0.51 & 0.12 & 0.36 & 0.65 & 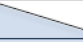 & 0.67 & 0.42 & -0.04 & 0.57 & 0.04 \\
\hline $\mathrm{Cl}$ & 0.74 & $\underline{0.99}$ & 0.20 & 0.50 & $\underline{0.90}$ & 0.49 & $\mathrm{X}^{2}$ & -0.03 & 0.16 & 0.23 & 0.11 \\
\hline $\mathrm{Zn}^{++}$ & 0.31 & $\overline{0.12}$ & 0.09 & 0.38 & $\overline{0.22}$ & 0.54 & 0.12 & $\gamma$ & 0.21 & 0.51 & 0.34 \\
\hline $\mathrm{Fe}^{++}$ & 0.45 & -0.02 & -0.06 & 0.14 & 0.30 & 0.10 & -0.03 & -0.02 &  & 0.49 & 0.78 \\
\hline $\mathrm{Cu}^{++}$ & 0.62 & 0.07 & 0.08 & 0.39 & 0.41 & 0.45 & 0.07 & 0.48 & 0.69 & 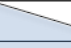 & 0.65 \\
\hline $\mathrm{Pb}^{++}$ & 0.48 & 0.00 & -0.07 & 0.19 & 0.32 & -0.02 & -0.01 & -0.04 & 0.87 & 0.74 & \\
\hline
\end{tabular}

Table 4. Correlation coefficients $r$ for dew (clear portion) and rain (shaded portion). Boldunderlined figures correspond to correlation higher than 0.9.

Concerning rain, four important correlations ( $>0.9$ ) were found. The correlation between $\mathrm{Na}^{+}$ and $\mathrm{Cl}^{-}$corresponds to marine origin. The correlation between $\mathrm{Ca}^{2+}$ and $\mathrm{SO}_{4}{ }^{2-}$ is of continental and anthropogenic origin. The high correlations of $\mathrm{SO}_{4}{ }^{2-}$ in rain with $\mathrm{Na}^{+}(0.91)$ and $\mathrm{Cl}^{-}(0.90)$ are due to long range transport of air masses bringing rain often influenced by maritime regions. The correlation of $\mathrm{SO}_{4}{ }^{2-}$ in dew with $\mathrm{Na}^{+}(0.41)$ and $\mathrm{Cl}^{-}(0.87)$ is significantly lower due to more local (anthropogenic) pollutant influence.

Three correlations are found important in dew (>0.9). A strong correlation is between $\mathrm{Na}^{+}$ and $\mathrm{Cl}^{-}$and $\mathrm{Mg}^{2+}$ and $\mathrm{Cl}^{-}$, indicating a marine origin. A strong indirect correlation is also found between $\mathrm{Na}^{+}$and $\mathrm{Mg}^{2+}$, presumably of marine origin. As an example, one has plotted in Fig.7 the correlation between $\mathrm{Cl}^{-}$and $\mathrm{Na}^{+}$, for both dew and rain. A linear fit $\left[\mathrm{Cl}^{-}\right]=\gamma\left[\mathrm{Na}^{+}\right]$ give (dew) $\gamma=1.15 \pm 0.06, \mathrm{r}=0.92$ and (rain) $\gamma=0.87 \pm 0.01, \mathrm{r}=0.99$. (Uncertainty is one standard deviation). 



Fig. 7. Correlation between $\mathrm{Cl}^{-}$and $\mathrm{Na}^{+}$.(a): Dew, (b): Rain. Lines are fits (see text).

\subsection{Marine contribution}

In order to measure the marine contribution of dew and rain ions, the sea salt fraction (SSF) and non-sea-salt fraction (NSSF) of marine salts were calculated. The totality of $\mathrm{Na}+$ considered of sea origin is the principal reference of the present calculation (Keene et al., 1986; Kulshrestha et al., 1996; Al Obaidy and Himanshu Joshi, 2006) as well as the ionic concentration of sea water given by Riley and Chester (1971). The parameters SSF and NSSF are thus calculated from the following equations:

$$
\begin{aligned}
& \%(S S F)_{X}=\frac{100 \times(N a)\left(\frac{X_{\text {Sea }}}{N a_{\text {Sea }}}\right)}{X} \\
& \%(N S S F)_{X}=100-\%(S S F) X
\end{aligned}
$$

Here $X$ is the concentration of ions as measured in dew and rain water, $\left(X_{\text {sea }}\right)$ is the concentration of the sea water ions, and $\left(\mathrm{Na}_{\text {sea }}\right)$ the concentration of the sodium ion taken as a 
reference in sea water. All concentrations are expressed in meq/l. The results are presented in Table 5.

For both dew and rain water, the marine contribution for $\mathrm{Mg}^{2+}$ and $\mathrm{Cl}^{-}$is clear, corresponding to sea salt particles in the atmosphere. The outsized values of chloride contribution in dew water (SSF=120\%) and, to a lesser extent, magnesium (SSF=104\%) are presumably due to the uncertainties in concentrations. Large NSSF (nearly 100\%) values for ions $\mathrm{SO}_{4}{ }^{2-}, \mathrm{NO}_{3}{ }^{-} \mathrm{Ca}^{2+}$, $\mathrm{K}^{+}$in dew and rain water indicate anthropogenic sources for these ions.

\begin{tabular}{c||c|c||c|c}
\multicolumn{1}{c||}{\multirow{2}{*}{\multicolumn{1}{c||}{ Ions }}} & \multicolumn{2}{c||}{ Dew } & \multicolumn{2}{c}{ Rain } \\
\cline { 2 - 5 } & SSF (\%) & NSSF (\%) & SSF (\%) & NSSF (\%) \\
\hline \hline $\mathrm{Mg}^{2+}$ & $\mathbf{1 0 4}$ & -4 & $\mathbf{7 8}$ & 22 \\
\hline $\mathrm{K}^{+}$ & 13 & $\mathbf{8 7}$ & 6 & $\mathbf{9 4}$ \\
\hline $\mathrm{Ca}^{2+}$ & 2 & $\mathbf{9 8}$ & 1 & $\mathbf{9 9}$ \\
\hline \hline $\mathrm{Cl}^{-}$ & $\mathbf{1 2 0}$ & -20 & $\mathbf{7 7}$ & 23 \\
\hline $\mathrm{SO}_{4}{ }^{2-}$ & 6 & $\mathbf{9 4}$ & 6 & $\mathbf{9 4}$ \\
\hline $\mathrm{NO}_{3}{ }^{-}$ & 0 & $\mathbf{1 0 0}$ & 0 & 100
\end{tabular}

Table 5. Sea salt water contribution (SSF) and non sea salt water contribution (NSSF). In bold are indicated the largest contributions.

\subsection{Neutralisation factor}

The acid ions $\left(\mathrm{SO}_{4}{ }^{2-}, \mathrm{NO}_{3}{ }^{-}\right)$contained in dew and rain water react with the base components $\mathrm{Ca}^{2+}, \mathrm{Mg}^{2+}, \mathrm{K}^{+}$. During this reaction, acidity disappears and water becomes nearly neutral. In order to determine the part played by the cations to neutralize the sulfuric and nitric acids, a factor of neutralization can be calculated according to:

$$
N F_{x}=\frac{[X]}{\left[N O_{3}^{-}+S O_{4}^{2-}\right]}
$$


Here $X$ is the species responsible for neutralization (Table 6). The high concentration of $\mathrm{Ca}^{2+}$ ions compared to the other ions in dew and rainwater implies that it is the more neutralizing cation, showing the strongest neutralization factor, followed by $\mathrm{Mg}^{2+}$ and $\mathrm{K}^{+}$. The $\mathrm{NF}$ for $\mathrm{Ca}^{2+}$ in dew and rain are similar.

\begin{tabular}{c||c|c} 
Ions & Dew NF & Rain NF \\
\hline \hline $\mathrm{Ca}^{2+}$ & 1.0 & 1.1 \\
\hline $\mathrm{Mg}^{2+}$ & 0.09 & 0.1 \\
\hline $\mathrm{K}^{+}$ & 0.07 & 0.1
\end{tabular}

Table 6. Neutralization factor (NF).

It is thus interesting to plot (Fig. 8) the sum of acidifying anions $\left(\mathrm{SO}_{4}{ }^{2-}+\mathrm{NO}_{3}{ }^{-}\right)$with respect to the most alkaline cations $\left(\mathrm{Ca}^{2+}+\mathrm{Mg}^{2+}\right)$ in meq/l. Linear fit of the data to $\left[\mathrm{SO}_{4}+\mathrm{NO}_{3}\right]=$ $\delta[\mathrm{Ca}+\mathrm{Mg}]$ (in meq/l) gives (dew) $\delta=(0.64 \pm 0.05), \mathrm{r}=0.75$ and (rain) $\delta=0.73 \pm 0.02, \mathrm{r}=$ 0.94. (Uncertainties: one standard deviation). The ratio of total alkalinity/total acidity $\left(\mathrm{SO}_{4}{ }^{2-}+\right.$ $\left.\mathrm{NO}_{3}{ }^{-}\right) /\left(\mathrm{Ca}^{2+}+\mathrm{Mg}^{2+}\right)$ (mean concentrations in meq/l) is lower than 1 for both dew and rain water, with nearly the same values (dew: 0.89; rain: 0.87), indicating that water alkalinity is comparable for dew and rain.

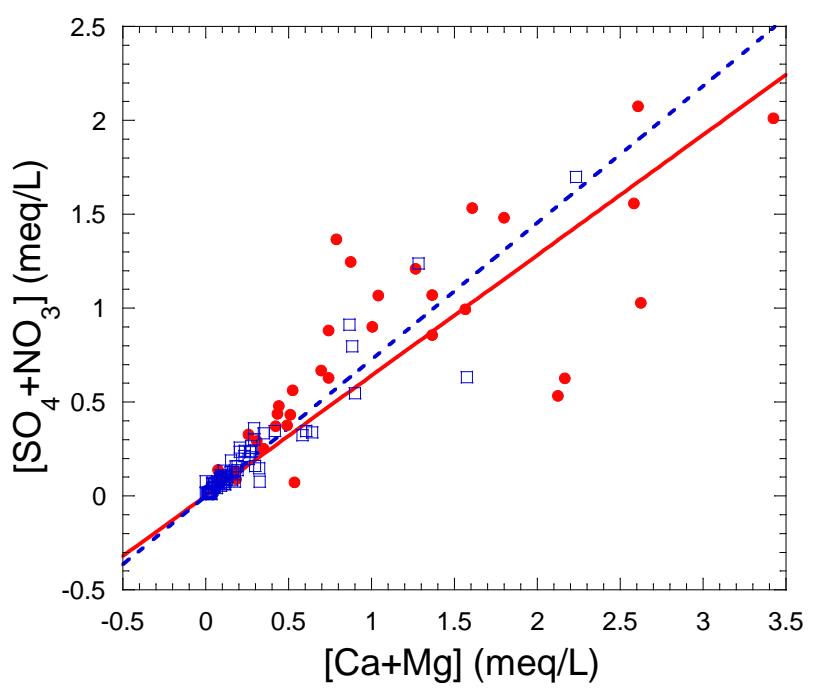

Fig. 8. Acidification process: Relationship between the sum of alkaline cations $\left(\mathrm{Ca}^{2+}+\mathrm{Mg}^{2+}\right)$ and acidifying anions $\left(\mathrm{SO}_{4}{ }^{2-}+\mathrm{NO}_{3}{ }^{-}\right)$. Full circles: dew; open squares: rain. The full lines are linear fits (see text). Full line: dew; interrupted line: rain. 


\section{Conclusion}

The analysis of one year measurement (01/04/2011 - 31/03/2012) of dew-rain frequency and volume in the historical center of Paris shows relatively small number of dew events (63 measured; 74 calculated from meteo data) compared to the estimate at a close location outside the city (Paris-Orly: 146 events). The low dew yields in Paris-center (3.5 mm measured, 2.5 mm estimated) when compared to Paris-Orly (estimated $17 \mathrm{~mm}$ ) is not due to a limited sky factor downtown Paris but rather to the presence of heat island that increases air temperature and lowers relative humidity. Rain statistics downtown Paris and Paris-Orly were found comparable (146 events for 590 mm downtown, 107 events for $547 \mathrm{~mm}$ in Paris-Orly).

The physico-chemical analysis of 34 dew and 77 rain samples show that dew and rain $\mathrm{pH}$ are nearly neutral with however rain being slightly more acidic than dew. This is in agreement with its lower neutralization factor. The mean dew total ionic content (TIC $1.8 \mathrm{meq} / \mathrm{l}$ ) and EC value $\left(124 \mu \mathrm{S} . \mathrm{cm}^{-1}\right)$ are about four times that of rain $\left(0.45 \mathrm{meq} / \mathrm{l} ; 35 \mu \mathrm{S} . \mathrm{cm}^{-1}\right)$, meaning that total dissolved solids in dew is nearly four times that in rain. Chemical composition of dew and rain water keeps similar trends. It reveals the importance of $\mathrm{Ca}^{2+}$ and $\mathrm{Na}^{+}$cations and $\mathrm{SO}_{4}{ }^{2-}, \mathrm{NO}_{3}{ }^{-}$et $\mathrm{Cl}^{-}$anions. Sulfate and nitrate are the most acidifying components, calcium the most neutralizing constituent with ratio of total acidity/ total alkalinity comparable for dew and rain $(\approx 0.9)$. The calculation of the sea salt fraction shows that only $\mathrm{Cl}^{-}$and $\mathrm{Mg}^{2+}$ are influenced by the distance from the sea. $\mathrm{Ca}^{2+}, \mathrm{SO}_{4}{ }^{2-}, \mathrm{NO}_{3}{ }^{-}$and $\mathrm{NO}_{2}{ }^{-}$are of anthropogenic origin (domestic and heating fuels, road traffic, road and building carbonate particles).

It is interesting to note that, although being collected in strongly urbanized environment, both dew and rain water quite generally respect the requirements of WHO for drinking water. This result is encouraging as it indicates that rain and dew water could be exploited at a certain level.

\section{Acknowledgments}

We gratefully thank C. Ohayon from Laboratoire d'Hydrologie d'Aquitaine for chemical analyses and M. Amal for help in analyzing the chemistry data. 


\section{References}

Acker, K., Moeller, D., Auel, R., Wieprecht, W., Kalaß, D., 2005. Concentrations of nitrous acid, nitric acid, nitrite and nitrate in the gas and aerosol phase at a site in the emission zone during ESCOMPTE 2001 experiment. Atmos. Res. 74, 507-524.

Acker, K., Beysens, D., Möller, D., 2008. Nitrite in dew, fog, cloud and rain water: an indicator for heterogeneous processes on surfaces. Atmos. Res. 87, 200-212.

Agam, N., Berliner, P.R., 2006. Dew formation and water vapor adsorption in semi-arid environments—a review. J. Arid Environ., 65, 572-590.

Air Quality in Europe, 2016. see http://www.airqualitynow.eu/city_info/paris/page2.php.

Alebić-Juretić, A., Sojat, V., 1998. Chemical composition of rainwater collected at two sampling sites in the city of Rijeka. Arh hig rada toksikol 49, 245-250.

Alicke, B., Geyer, A., Hofzumahaus, A., Holland, F., Konrad, S., Pätz, H.W., Schäfer, J., Stutz, J., Volz-Thomas, A., Platt, U., 2003. OH formation by HONO photolysis during the BERLIOZ experiment. J. Geophys. Res. 108 (D4), 8247.

Al Obaidy, Abdul Hameed M.J., Joshi, H., 2006. Chemical composition of rainwater in a tropical urban area of northern India. Atmos. Environ. 40, 6886-6891.

Atekwanaa, E.A., Atekwanaa, E.A., Rowe, R.S., Werkema Jr., D.D., Legall, F.D., 2004. The relationship of total dissolved solids measurements to bulk electrical conductivity in an aquifer contaminated with hydrocarbon. J. Appl. Geophys. 56, 281- 294.

Berger, X., Bathiebo, J., Kieno, F., Awanou, C.N., 1992. Clear sky radiation as a function of altitude. Renew Energ. 2, 139-157.

Berkowicz, S., Beysens, D., Milimouk, I., Heusinkveld, B.G., Muselli, M., Wakshal, E., Jacobs, A.F.G., 2004. Urban dew collection under semi-arid conditions, Jerusalem. Proc. of the Third International Conference on Fog, Fog Collection and Dew, Cape Town, South Africa, Oct 11-15, 2004. pp. E4-7.

Beysens, D., 1995. The formation of dew. Atmos. Res. 39, 215-237.

Beysens D., Milimouk, I., 2000. "Pour des ressources alternatives en eau”, Sécheresse 11, 281-288.

Beysens, D., 2006. Dew nucleation and growth, C. R. Physique 7, 1082-1100.

Beysens, D., Muselli, M., Milimouk, I., Ohayon, C., Berkowicz, S., Soyeux, E., Mileta, M., Ortega, P., 2006a. Application of passive radiative cooling for dew condensation. Energy 31, 1967-1979. 
Beysens, D., Ohayon, C., Muselli, M., Clus, O., 2006b. Chemical and biological characteristics of dew and rain water in an urban coastal area (Bordeaux, France). Atmos. Environ., 40, 3710-3723.

Beysens, D., Clus, O., Mileta, M., Milimouk, I., Muselli, M., Nikolayev, V.S., 2007.

Collecting dew as a water source on small islands: the dew equipment for water project in Bisevo (Croatia). Energy 32, 1032-1037.

Beysens, D., 2016. Estimating dew yield worldwide from a few meteo data. Atmos. Res. 167, 146-155.

Buijsman, E., Erisman, J.W., 1988. Wet deposition of ammonium in Europe. J. Atmos. Chem. 6, 265-280.

Cantat, O., 2004. Paris urban heat island according to weather categories. Norois, 191, 75-102 (in French).

Doppelt, E., Beysens, D., 2013. Better collection of dew and weak precipitations. ESPCIPMMH internal report.

Gałek, G., Sobik, M., Błas, M., Polkowska, Z., Cichała-Kamrowska, K., 2015a. Urban dew formation efficiency and chemistry in Poland. Atmos. Pollution Res. 7, $18-24$.

Gałek, G., Sobik, M., Błas, M., Polkowska, Z., Cichała-Kamrowska, K., Wałaszek, K., 2015b. Dew and hoarfrost frequency, formation efficiency and chemistry in Wroclaw, Poland. Atmos. Res. 151, 120-129.

Glossary of Meteorology (2009). Urban heat Island. American Meteorological Society.

Jacobs, A.F.G., Heusinkveld, B.G., Wichink Kruit, R.J., Berkowicz, S.M., 2006. Contribution of dew to the water budget of a grassland area in The Netherlands. Water Resour. Res. 42., W03415.

Jiries, A., 2001. Chemical composition of dew in Amman, Jordan. Atmos. Res. 57, 261-268.

Keene, W.C., Pszenny, A.P., Galloway, J.N., Hawley, M.E., 1986. Sea salt corrections and interpretations of constituent ratios in marine precipitation. J. Geophys. Res. 91, 6647-6658.

Khalil, B., Adamowski, J., Shabbir, A., Jang, C., Rojas, M., Reilly, R., Ozga-Zielinski, B., 2016. A review, dew water collection from radiative passive collectors to recent developments of active collectors. Sustainable Water Resource Management (online), DOI 10.1007/s40899-015-0038-z.

Kidron, G.J., 2000. Analysis of dew precipitation in three habitats within a small arid drainage basin, Negev Highlands, Israel. Atmos. Res. 55, 257-270.

Kidron, G.J., Temina, M., Starinsky, A, 2011. An Investigation of the Role of Water (Rain and Dew) in Controlling the Growth Form of Lichens on Cobbles in the Negev Desert. Geomicrobiol. J., 28, 335-346. 
Kulshrestha, U.C., Sarkar, A.K., Srivastava, S.S., Parashar, D.C., 1996. Investigation into atmospheric deposition through precipitation studies at New Delhi (India). Atmos. Environ. 30, 4149-4154.

Lekouch, I., Mileta, M., Muselli, M., Milimouk-Melnytchouk, I., _Sojat, V., Kabbachi, B., Beysens, D., 2010. Comparative chemical analysis of dew and rain water. Atmos. Res. 95, 224-234.

Lekouch, I., Muselli, M., Kabbachi, K., Ouazzani, J., Melnytchouk-Milimouk, I., Beysens, D., 2011. Dew, fog, and rain as supplementary sources of water in south-western Morocco. Energy 36, 2257-2265.

Lekouch, I., Lekouch, K., Muselli, M., Mongruel, A., Kabbachi, K., Beysens, D., 2012. Rooftop dew, fog and rain collection in southwest Morocco and predictive dew modelling using neural networks. J. Hydrol. 448-449, 60-72.

Luo, W., and Goudriaan, J., 2000. Dew formation on rice under varying durations of nocturnal radiative loss. Agric. For. Meteorol., 104, 303-313.

Meteo-France, 2016. http://www.meteofrance.com/climat/france/paris/75114001/normales

Monteith, J.L., Unsworth, M.H., 1990. Principles of Environmental Physics (2 ${ }^{\text {nd }}$ edition). Routledge, Chapman and Hall, Inc., New-York.

Muselli, M., Beysens, D., Soyeux, E., Clus, O., 2006. Is dew water potable? Chemical and biological analyses of dew water in Ajaccio (Corsica Island, France). J. Environ. Quality, 35, 1812-1817.

Muskała, P., Sobik, M., Błaś, M., Polkowska, Ż., Bokwa, A., 2015. Pollutant deposition via dew in urban and rural environment, Cracow, Poland. Atmos. Res., 151, 110-119.

Mylymuk-Melnytchouk, I., Beysens, D., 2016. Puits aériens : mythes et réalités ou Travaux russes \& soviétiques sur la production d'eau à partir de l'air, Editions Universitaires Européennes (2016) ; ISBN 978-3-639-48096-2

Nilsson, T., 1996. Initial experiments on dew collection in Sweden and Tanzania. Sol. Energy Mater. Sol. Cells 40, 23-32.

Okochi, H., Kajimoto, T., Arai, Y., Igawa, M., 1996. Effect of acid deposition on urban dew chemistry in Yokohama, Japan. Bull. Chem. Soc. Jpn. 69, 3355-3365.

Okochi, H., Sato, E., Matsubayashi, Y., Igawa, M., 2008. Effect of atmospheric humiclike substances on the enhanced dissolution of volatile organic compounds into dew water. Atmos. Res. 87, 213-223.

OPUR, 2016. see www.opur.fr.

Ortiz, V., Rubio, M.A., Lissi, E.A., 2000. Hydrogen peroxide deposition and decomposition in rain and dew waters. Atmos. Environ. 34, 1139-1146. 
Pal Arya, S., 1988. Introduction to Micrometeorology. Academic Press, Inc., San Diego.

Pascaud, A., Sauvage, S., Coddeville, P., Nicolas, M., Croisé, L., Mezdour, A., Probst, A., 2016. Contrasted spatial and long-term trends in precipitation chemistry and deposition fluxes at rural stations in France. Atmos. Environ. 146, 28-43.

Polkowska, Z., Błas, M., Klimaszewska, K., Sobik, M., Małek, S., Namiesnik, J., 2008. Chemical characterization of dew water collected in different geographic regions of Poland. Sensors 8, 4006-4032.

Richards, K., 2002. Hardware scale modeling of summertime patterns of urban dew and surface moisture in Vancouver, BC, Canada. Atmos. Res. 64, 313-321.

Richards, K., 2005. Urban and rural dewfall, surface moisture, and associated canopy-level air temperature and humidity measurements for Vancouver, Canada. Bound-Lay Meteorol. 114, 143-163.

Riley, J.P., Chester, R., 1971. Introduction to Marine Chemistry. Academic Press, London and New York.

Rubio, M.A., Lissi, E., Riveros, V., Paez, M., 2001. Remoción de contaminantes por lluvias y rocíos en la región metropolitana. J. Chil. Chem. Soc. 46, 353-361.

Rubio, M.A., Lissi, E., Villena, G., 2002. Nitrite in rain and dew in Santiago city, Chile. Its possible impact on the early morning start of the photochemical smog. Atmos. Environ. 36, 293-297.

Rubio, M.A., Guerrero, M.J., Villena, G., Lissi, E., 2006. Hydroperoxides in dew water in downtown Santiago, Chile. A comparison with gas-phase values. Atmos. Environ. 40, 61656172.

Rubio, M.A., Lissi, E., Villena, G., 2008. Factors determining the concentration of nitrite in dew from Santiago, Chile. Atmos. Environ. 42, $7651 \mathrm{e} 7656$.

Takeuchi, M., Okochi, H., Igawa, M., 2001. Dominant factors of major and minor components and formation of hydroxyl alkane sulfonate in urban dew water. Water Air Soil Pollut. 130, 613-618.

Takenaka, N., Soda, H., Sato, K., Terada, H., Suzue, T., Bandow, H., Maeda, Y., 2003. Difference in amounts and composition of dew from different types of dew collectors. Water Air Soil Pollut. 147, 51-60.

Tomaszkiewicz, M., Najm, M. A., Beysens, D., Alameddine, I., El-Fadel, M., 2015. Dew as a Sustainable Non-Conventional Water Resource, A Critical Review. Environ. Rev. 23, 1-18.

Uclés, O., Villagarcía, L., Moro, M.J., Canton, Y. Domingo, F., 2013. Role of dewfall in the water balance of a semiarid coastal steppe ecosystem. Hydrol. Process 28, 2271-2280.

vanLoon, G.W., Duffy, S.J., 2011. Environmental chemistry: A global perspective. $3^{\text {rd }}$. ed., Oxford University Press Inc., New York, pp. 544 
World meteorological organization global atmosphere watch, 2004. Manual for the GAW precipitation chemistry program. (Report no. 160).

WHO pH revised, 2007. $\mathrm{pH}$ in Drinking-water. Revised background document for development of WHO Guidelines for Drinking-water Quality, WHO/SDE/WSH/07.01/1.

Xu, N., Zhao, L., Ding, C., Zhang, C., Li, R., Zhong, Q., 2001. Laboratory observation of dew formation at an early stage of atmospheric corrosion of metals. Corros. Sci. 44, 163-170.

Xu, Y., Zhu, H. , Tang J., Lin, Y. 2015. Chemical Compositions of Dew and Scavenging of Particles in Changchun, China. Adv. Meteorol. 2015, 104048.

Yadav, S., Kumar, P., 2014. Pollutant scavenging in dew water collected from an urban environment and related implications. Air Quality, Atmosphere \& Health 7, 559-566.

Ye, Y., Zhou, K., Song, L., Jin, J., and Peng, S., 2007. Dew amounts and its correlations with meteorological factors in urban landscapes of Guangzhou, China. Atmos. Res., 86, 21-29.

Zangvil, A., 1996. Six years of dew observations in the Negev Desert, Israel. J. Arid Environ. 32, 361-371. 